\title{
REVIEW ARTICLE 19th-century and early 20th-century jaundice outbreaks, the USA
}

\author{
C. G. TEO* \\ 1333 Jones Street, San Francisco, CA 94109, USA
}

Received 9 May 2017; Final revision 2 October 2017; Accepted 15 November 2017; first published online 19 December 2017

\section{SUMMARY}

Historical enquiry into diseases with morbidity or mortality predilections for particular demographic groups can permit clarification of their emergence, endemicity, and epidemicity. During community-wide outbreaks of hepatitis A in the pre-vaccine era, clinical attack rates were higher among juveniles rather than adults. In community-wide hepatitis $E$ outbreaks, past and present, mortality rates have been most pronounced among pregnant women. Examination for these characteristic predilections in reports of jaundice outbreaks in the USA traces the emergence of hepatitis A and also of hepatitis $\mathrm{E}$ to the closing three decades of the 19th century. Thereafter, outbreaks of hepatitis A burgeoned, whereas those of hepatitis E abated. There were, in addition, community-wide outbreaks that bore features of neither hepatitis A nor E; they occurred before the 1870s. The American Civil War antedated that period. If hepatitis A had yet to establish endemicity, then it would not underlie the jaundice epidemic that was widespread during the war. Such an assessment may be revised, however, with the discovery of more extant outbreak reports.

Key words: Hepatitis (general), Hepatitis A, Hepatitis E.

\section{INTRODUCTION}

'I have met in a morning's walk successively a lawyer, a plumber, and a college student each going about his respective business, and each with a skin as yellow as an orange ... But the cases have occurred principally among the young, and in that class the disease has been epidemic.'

So remarked Sweet, a physician in Geneva, New York, of a visitation of jaundice in his hometown in 1887 [1]. He was intrigued not only that the outbreak was widespread but also that children were particularly affected. Specifically, 'Children from 6 to 12 years of age have for the most part been the subjects of the malady [1].' Earlier, regarding the 1881 jaundice outbreak in Washington, D.C., Garnett commented, 'it has not hitherto occurred to me to meet with this disease in the form of an epidemic confining its attacks exclusively

\footnotetext{
* Author for correspondence: 1333 Jones Street, San Francisco, CA 94109, USA.

(Email: teocg1@hotmail.com)
}

to young children [2].' Davis, from Chicago, averred, 'Epidemic jaundice among children is of very exceptional occurrence [3].' Across Maine in the decade before and continuing to the next century - exemplified by the reports of outbreaks in Cumberland County (1869) [4], multiple locations in the state including Minot (1886-1890) [5] and Andover with its neighbouring logging camps (1909) [6] - the emergence of epidemic jaundice striking children primarily was also becoming notable.

What Sweet, Garnett and their contemporaries were witnessing was the harbingering of a new wave of jaundice epidemics in the USA, beginning in the 1870s. The documentations of Neill [7] and Blumer [8] confirmed that epidemics started becoming widespread during the closing decades of the 19th century. Blumer enumerated eight of 59 jaundice outbreaks (14\%) between 1812 and 1886 (confined mostly to the south of the Mason-Dixon line), but 51 (86\%) during the short period from 1886 to 1920 (dispersed across the country) [8]. 
Thereafter, the number of outbreaks rose even more markedly. From 1920 through to 1922, >200 outbreaks struck New York State alone [9]. By then, demographic features considered atypical by the 19th-century observers [1-6] had become hallmarks of the epidemic: highest clinical attack rates among children $<15$ years compared with older age-groups; no significant difference in attack rates between males and females; and higher morbidity and fatality rates among young children $(<5$ years) compared with older children (5-14 years). These characteristics define community-wide hepatitis $\mathrm{A}$ in the pre-vaccine era [10-15]. Through the greater duration of the 20th century, epidemics continued cyclically. They led to large-scale administration of pooled gamma globulin for prophylaxis of exposed contacts (Fig. 1). The epidemics were held in abeyance only in the 1990s with the introduction of routine vaccination against hepatitis A in children [16].

\section{THE ENQUIRY}

Some of the outbreaks documented by Neill [7] and Blumer [8] did not show a predilection for children and early adolescents (hereafter, 'juveniles'), which would suggest that they were not hepatitis A. If so, what other diseases might underlie those non-juvenile-predominant outbreaks? That question is addressed in the first part of the enquiry. The enquiry is then extended to examine if hepatitis A could be associated with the jaundice epidemic of the American Civil War, which broke out before the 1870s, the period when epidemic hepatitis A had not yet emerged.

\section{PRELIMINARY CONSIDERATIONS}

\section{Varieties of epidemic jaundice}

Up to the end of the 19th century, the causes of epidemic jaundice were unknown. The discovery of what is now called Leptospira hemorraghica during World War I [7] led to the distinction of 'spirochetal' jaundice (subsequently termed leptospirosis) and Weil's disease from the more benign forms of epidemic jaundice. One variant, essentially the 'filth disease' form, was associated with outbreaks in military and civilian populations, and was called variously 'epidemic catarrhal jaundice', 'infective hepatitis', 'infectious hepatitis', 'epidemic hepatitis', etc. [17]. Another variant, transmitted from syringes, was referred to as serum or homologous serum hepatitis.
Following definitive human transmission experiments during World War II, these two forms came to be known as hepatitis A and hepatitis B [18], the prototypes of faecal-orally transmitted and blood-borne hepatitis, respectively. Subsequently, faecal-orally transmitted hepatitis resolved to hepatitis $\mathrm{A}$ and $\mathrm{E}$, and blood-borne hepatitis to hepatitis B, C and D. The pathogens causing these hepatitides - all viruses - bear alphabetical assignments corresponding to the diseases, i.e. hepatitis viruses A to E.

\section{Toxic jaundice}

Epidemic jaundice need not always ensue from microbial infection. Nonetheless, all outbreaks considered in the current enquiry have not been reported to be associated with exposure to hepatotoxins [19]. They are therefore presumed to be infectious in origin.

\section{Sporadic jaundice}

Past descriptions of painless jaundice - the principal clinical manifestation of a viral hepatitide - potentially provide nosologic clues. (Distinction is made between painless and painful jaundice. The latter points to a disparate class of disease, one associated with biliary obstruction, of which cholelithiasis is prominent [20].) Records of painless jaundice that ran a benign course and occurring sporadically in the American Continent date back to the 17th and 18 th centuries, and are exemplified by the correspondence in 1682 between the sons of the Rev. Richard Mather of Massachusetts [21], and the reminiscences of Dr Jacob Roebeck whose practice in the 1790s was based in Grand Isle, Vermont [22]. However, the information therein and in such like documents does not permit inferences of which disease underlay the occasions of jaundice. With regard to sporadic, fatal jaundice in pregnancy, the earliest documentation is in the form of a case report of 'leucinosis' published in 1867 [23]. Autopsy revealed a shrunken liver, with microscopy showing replacement of hepatocytes by fatty globules, pointing to the acute fatty liver of pregnancy rather than a viral hepatitide. Prospects of identifying the cause(s) of sporadic, painless jaundice from historical records are dim.

\section{Community vs. military and institutional epidemics}

Community outbreaks tend to originate from persons from a wide age range and both sexes. If the disease in 


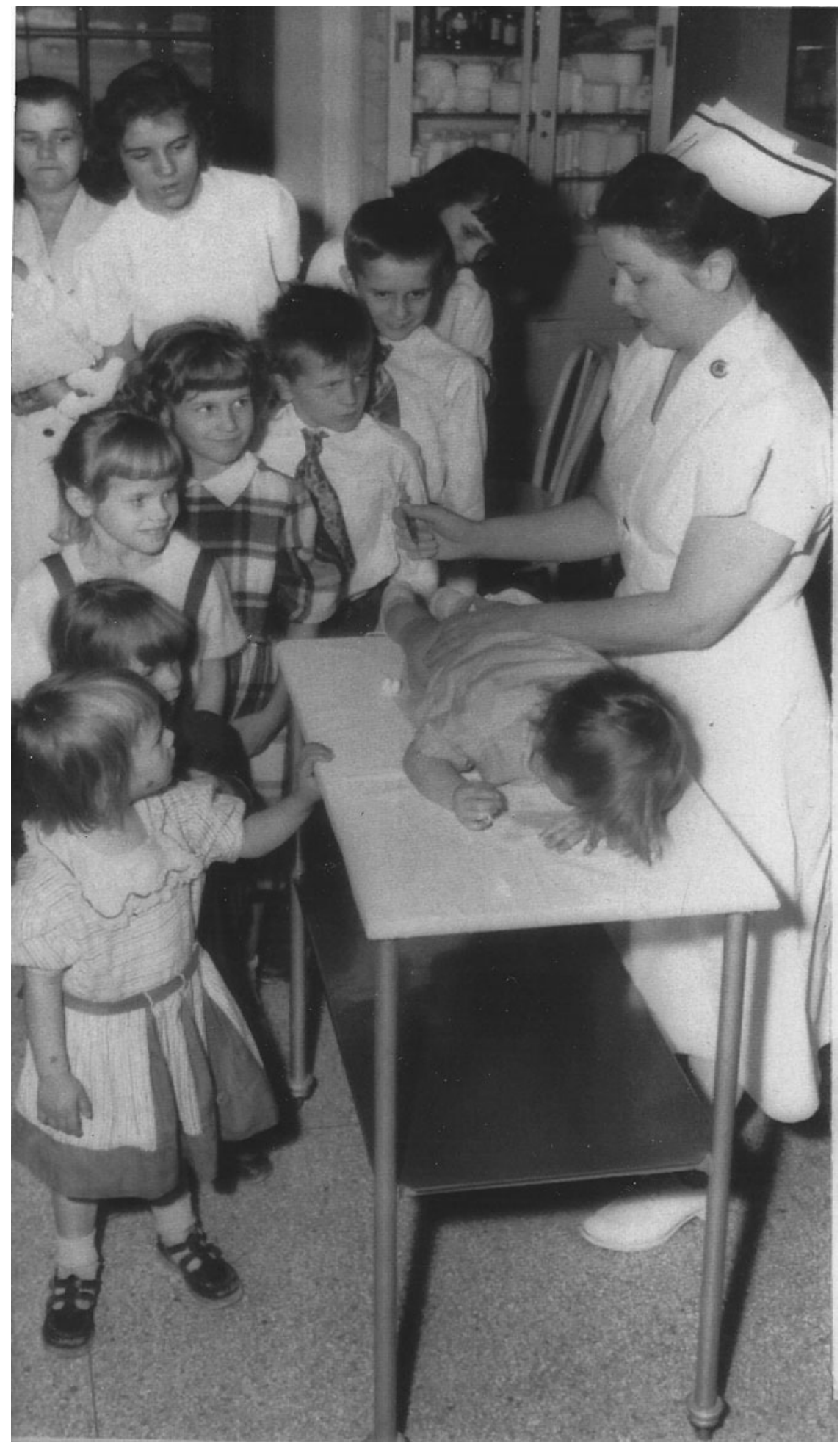

Fig. 1. Ten children of the Heckmann family lining up for gamma globulin shots at the Children's Hospital, Pittsburgh, during an outbreak of jaundice (1954). Nurse administering an injection to a boy atop a table, with mother at the end of the line carrying an infant (partially out of view). (Credit: United Press.).

question exhibits a predilection for a particular population group, community-wide outbreaks can permit assessments of disease causation. Mortality and morbidity data pertaining to military outbreaks concern males in their adolescence through to middle-aged adulthood, so are too circumscribed 
demographically for inferring what the causative disease might be. Similarly, data from outbreaks in civilian institutional populations, e.g., schools, colleges, hostels and workplaces, also tend to be associated with specific age-groups and sex.

\section{THE FIRST ENQUIRY}

The initial enquiry examines what non-hepatitisA-like diseases might underlie the jaundice outbreaks of the 19th century and early 20th century. These were outbreaks for which the cases were non-juvenile predominant.

Reports of jaundice outbreaks were examined, guided by the documentations of Neill [7] and Blumer [8]. Other publications outside their purview were also looked into. Military and civilian institutional outbreaks were excluded from this phase of the enquiry.

Altogether, nine community-wide, non-juvenilepredominant outbreaks were considered [24-32]. Observational data reported from them are summarised in Table 1. The outbreaks can be classified into two groups: Group I $(n=5)$, notable for coma or fatality in pregnant women, with or without data indicating excess cases of jaundice among adults; and Group II $(n=4)$, not notable for coma or fatality in pregnant women but with excess cases of jaundice among non-juveniles. The Group I outbreaks happened later (1873-1907) than those in Group II (1839-1860) (Fig. 2).

\section{Hepatitis E-like epidemics}

In the Group I outbreaks, almost all the pregnant women developed coma $(n=12)$ or died comatose $(n=11)$, mostly during the $3^{\text {rd }}$ trimester. Another feature was the high number of intrauterine and neonatal deaths (>11) among the affected women (Table 1).

Reports of outbreaks from Group I display interesting features. In Smith's report [24], jaundice in St. Paul, Minnesota, 'so generally spread that it might be said to have been an epidemic,' resolved 'in almost all instances.' But outcomes for ten cases - all pregnant women - were less salutary: three perished in a coma and miscarried; and five of the seven survivors also miscarried. The epidemic in Birmingham, Alabama, was reported by Sears [25] to have 'exhibited some peculiar features,' viz., five of 17 pregnant women among the cases died. All fatalities resulted 'not from the effects of fever, but from severe nervous symptoms, resulting in delirium, convulsions and coma.' Young's account of the jaundice outbreak in a Tennessean village [26] focused on three cases, all pregnant. Its space-time clustering is distinct: 'the victims lived in the same little village not more than 100 yards apart' and jaundice 'developed within a few days of each other.' Vividly described is the natural history of fulminant hepatitis in the index case. She was a 35-year-old grand multigravida, who, when first attended to, was in 'remarkably good spirits, laughing and jesting,' though deeply jaundiced. When visited again ten days later, coma had set in; by the next afternoon she had expired. In the outbreak in Clarksville, Tennessee, reported by Runyon [27], four pregnant women were among the cases; one died in a coma but the rest survived. The last outbreak in Group I, in Talladega, Alabama, would have been unremarkable if not for the mention of fatality in a pregnant woman and her infant [28].

In all Group I outbreaks, no deaths were reported other than among pregnant women. These outbreaks are redolent of classic (faecal-orally transmitted or waterborne) hepatitis E. Community-wide epidemic hepatitis E exhibits distinct demographic characteristics: highest clinical attack rates are observed among persons in the 15-44-year age group, with males predominating. Mortality is particularly heavy among women in gestation: whereas the case-fatality rate for the general population is seldom $>1 \%$, for pregnant women it can reach up to $50 \%$. Invariably, death is preceded by coma. Hepatitis A, in particular, is unlikely because of the exceeding rarity of pregnancy deaths associated with it. No epidemic disease other than hepatitis E, whether infective or toxic, shows such a peculiar, grave predilection for gestational women (to a lesser extent, parturient and postpartum women). This signature characteristic is the outcome of the propensity for hepatitis $\mathrm{E}$ virus (HEV) belonging to genotype 1 (more rarely, genotype 2) to trigger massive liver necrosis in gestational women, thereby leading to hepatic failure and encephalopathy. Intrauterine and neonatal deaths that frequently arise are due to vertical HEV transmission [33].

The Group I outbreaks happened over an approximate three-decade period (from the late 1880s to the first decade of the 20th century). It overlaps the period of emergence of hepatitis A (1-6) (Fig. 2). Their coevality suggests that hepatitis $\mathrm{E}$ either had previously established endemicity before that period, or was - like hepatitis A - also in emergence. Thereafter, given the absence of Group-1-like outbreaks after the 1907 Talladega epidemic [28] (Fig. 2), classic hepatitis E subsided - unlike hepatitis A, which continued to spread. 
Table 1. Non-juvenile-dominant, community-wide jaundice outbreaks in the USA, 19th century to early 20th century

\begin{tabular}{|c|c|c|c|c|c|c|c|}
\hline No. & Author & $\begin{array}{l}\text { Season and } \\
\text { year }\end{array}$ & Location & Case count & Demographic characteristics & No. comatose & No. deaths \\
\hline \multicolumn{8}{|c|}{ Epidemics with coma or fatality in pregnant women (Group I) } \\
\hline 1 & Smith [24] & $\begin{array}{l}\text { Summer and } \\
\text { fall, } 1873\end{array}$ & $\begin{array}{l}\text { Ramsay County, } \\
\text { St. Paul, } \\
\text { Minnesota }\end{array}$ & Not reported & $\begin{array}{l}\text { Not reported, other than ten women } \\
\text { pregnant (from } 2 \text { to } 8 \mathrm{~m} \text { gestation) }\end{array}$ & $\begin{array}{l}\text { Three (all } \\
\text { pregnant) }\end{array}$ & $\begin{array}{l}\text { Three comatose pregnant } \\
\text { women; eight miscarriages, } \\
\text { stillbirths or neonatal deaths }\end{array}$ \\
\hline 2 & Sears $[25]$ & $\begin{array}{l}\text { Fall of } 1881 \text { to } \\
\text { winter of } 1882\end{array}$ & $\begin{array}{l}\text { Birmingham, } \\
\text { Alabama }\end{array}$ & Not reported & $\begin{array}{l}\text { Not reported, other than } 17 \text { women } \\
\text { pregnant ( } 15 \text { from } 6 \frac{1}{2} \mathrm{~m} \text { to term) }\end{array}$ & Five (all pregnant) & $\begin{array}{l}\text { Five comatose pregnant } \\
\text { women; 'most' of pregnant } \\
\text { women 'aborted' }\end{array}$ \\
\hline 3 & Young [26] & 1898 & $\begin{array}{l}\text { A 'little' village in } \\
\text { Tennessee }\end{array}$ & Not reported & $\begin{array}{l}\text { Not reported, except for } 3 \text { pregnant } \\
\text { women including twins who lived very } \\
\text { near to index case ( } 6 \mathrm{~m} \text { gestation) }\end{array}$ & $\begin{array}{l}\text { Two (index case } \\
\text { and one twin, } 8 \mathrm{~m} \\
\text { gestation) }\end{array}$ & $\begin{array}{l}\text { One (index case); one stillbirth } \\
\text { (her infant) }\end{array}$ \\
\hline 4 & Runyon [27] & Fall, 1899 & $\begin{array}{l}\text { Clarksville, } \\
\text { Tennessee }\end{array}$ & 20 & $\begin{array}{l}\text { 'young or middle-aged and previously } \\
\text { healthy people;' mostly males; four } \\
\text { pregnant }\end{array}$ & $\begin{array}{l}\text { One }(81 / 2 \mathrm{~m} \\
\text { pregnant })\end{array}$ & $\begin{array}{l}\text { One (the comatose pregnant } \\
\text { woman); } 1 \text { stillbirth (her } \\
\text { infant) }\end{array}$ \\
\hline 5 & Dixon $[28]$ & Summer, 1907 & $\begin{array}{r}\text { Talladega, } \\
\text { Alabama }\end{array}$ & 200 & $\begin{array}{l}145 \text { men; } 30 \text { women (including one } \\
\text { pregnant 'just before confinement'); } 25 \\
\text { children (including } 8 \text { infants); ages not } \\
\text { specified }\end{array}$ & Not reported & $\begin{array}{l}\text { One (the pregnant woman); } \\
\text { one stillbirth (her infant) }\end{array}$ \\
\hline \multicolumn{8}{|c|}{ Epidemics without reported fatalities, with excess cases in non-juveniles (Group II) } \\
\hline 6 & Clark [29] & $\begin{array}{l}\text { Summer and } \\
\text { fall, } 1839\end{array}$ & $\begin{array}{l}\text { Jacksonville, } \\
\text { Alabama }\end{array}$ & Not reported & $\begin{array}{l}\text { 'almost exclusively adult males;' no } \\
\text { children }\end{array}$ & Not reported & 0 \\
\hline 7 & Corson $[30]$ & $\begin{array}{l}\text { Fall and winter, } \\
1854\end{array}$ & $\begin{array}{l}\text { Montgomery } \\
\text { County, } \\
\text { Pennsylvania }\end{array}$ & 38 & $\begin{array}{l}\text { Reported for } 28 \text { cases: } 5<15 \text { y; } 20 \geqslant 15 \text { to } \\
\leqslant 50 \text { y; } 3>50 \text { y; } 20 \text { males, eight females }\end{array}$ & Not reported & None; two neonatal deaths \\
\hline 8 & Pierson [31] & Fall, 1858 & Orange, New Jersey & $\begin{array}{l}>300 \text { (in } \\
\text { population of } \\
7000)\end{array}$ & $\begin{array}{l}\text { 'persons of all ages, although rarely those } \\
\text { under the age of puberty;' males }> \\
\text { females }\end{array}$ & Not reported & 0 \\
\hline 9 & $\begin{array}{l}\text { Schaffner } \\
\text { [32] }\end{array}$ & Fall, 1860 & $\begin{array}{l}\text { Salem, North } \\
\text { Carolina }\end{array}$ & $\begin{array}{l}125 \text { (in } \\
\text { population of } \\
1200 \text { ) }\end{array}$ & $\begin{array}{l}\text { 'rarely attacked persons under the age of } \\
\text { puberty' }\end{array}$ & Not reported & 0 \\
\hline
\end{tabular}




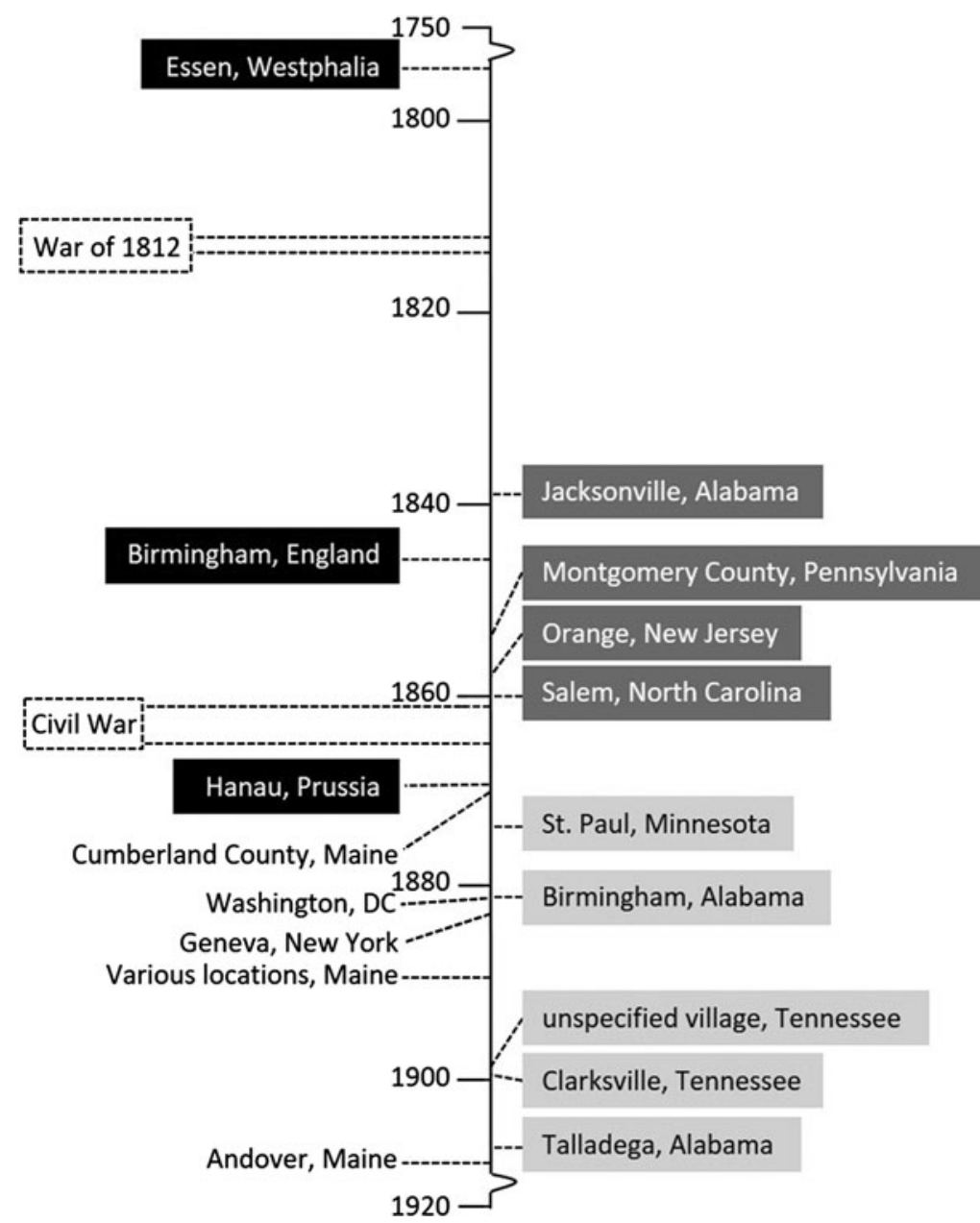

Fig. 2. Timeline of jaundice outbreaks specified in the current study. Light grey box: Group I outbreaks (non-juvenile-dominant); dark grey box: Group II outbreaks (non-juvenile-dominant); black box: juvenile-dominant outbreaks in Europe that preceded those in the United States; and unboxed: early juvenile-dominant outbreaks in the United States.

\section{Non-hepatitis-E-like outbreaks}

The four outbreaks in Group II (between 1839 and 1860) are noted for their preponderance in adults $[25,26]$ or rarity in persons 'under the age of puberty' $[31,32]$, and in males [29-31]. In none of the outbreaks were deaths reported (Table 1). Clark's account of the outbreak in Jacksonville, Alabama [29], is notable as a case series, among the earliest of its kind reported in the USA. Compared with that, the reports of Corson [30], Pierson [31] and Shaffner [32] are prosaic, with the possible exception of Pierson's description which noted that among those jaundiced were three of the five physicians practicing in Orange, New Jersey [31]. Population data were provided for the outbreak there, and the one in Salem, North Carolina [32], permitting calculation of clinical attack rates as being 1 and $4 \cdot 5 \%$, respectively.
The Group II epidemics are unlikely to be due to hepatitis $\mathrm{E}$, since no deaths were observed, let alone among pregnant women. Nor could they be hepatitis A, as they were not juvenile-predominant. Moreover, hepatitis A outbreaks with excess attack rates in nonjuveniles are consequences of lowered herd immunity that follow improvements in sanitation, hygiene and poverty: they are phenomena encountered in the modern era [34], not before World War I. Other icterogenic infectious diseases (e.g., leptospirosis, typhus, louse-borne relapsing fever, etc.) [35] are possibilities. These tend to be associated with extra-icteric features and high morbidity and mortality rates, whereas all the Group II outbreaks ran a benign course. Accordingly, non-A, non-E viral hepatitis may not be discounted. The features of these epidemics do not provide sufficient information to determine if they are from a single aetiology. 


\section{THE SECOND ENQUIRY}

The enquiry into community-wide jaundice outbreaks has provided a chronological perspective of the outbreak occurrences and an insight into what the causative agents may be. Those now permit an examination of what might underlie the military outbreaks in the 19th century, in particular, the great jaundice epidemic of the American Civil War.

\section{Preliminary consideration: contemporaneous epidemics in Europe}

In Europe, occurrences in the 19th century of the military, institutional and community-wide jaundice epidemics have amply been documented [36, 37] as have hepatitis E outbreaks in particular [33]. Like in the USA, outbreaks in Europe that were predominantly non-juvenile (i.e. similar to the Group II outbreaks), antedate those that were principally juvenile. These include military outbreaks. Notably, juvenilepredominant outbreaks in Europe preceded those in the USA [1-7], e.g. 1772 in Essen, Westphalia [38], 1852 in Birmingham, England [39] and 1868 in Hanau, Prussia [40] (Fig. 2). Descriptions of juveniledominant outbreaks in Europe started to burgeon from the late 19th century, flourishing as the next century arrived and progressed [41-43].

\section{Military epidemics in the USA}

In the USA, regimental outbreaks of jaundice have been reported, two during times of war and several more in between [44]. The first wartime outbreak happened sometime between 1812 and 1814, according to a report by Faulkner [45]; he alluded to a militia man who encountered jaundice in 'almost every man' in his company which was then mobilising in Virginia against the British [46]. A few decades later loomed the American Civil War (1861-1865). Jaundice was rife among the combatants, whether encamped, imprisoned or otherwise quartered. The medical corps of the Union Army recorded 87236 cases of jaundice [44]. Case counts for the Confederate Army were not as comprehensively compiled [47] but correspondences of field physicians provide insights into how widespread jaundice was [48, 49].

What caused these outbreaks? With regard to the War of 1812, no mention of extra-icteric features or deaths among the Virginian militiamen was made but the ailment seemed innocuous [45]. An enterically transmitted viral hepatitide could have been responsible. The epidemic in the Civil War was considered 'a troublesome and tedious, but not a dangerous affection [50],' although it elicited a 5\% case-fatality rate [44]. Coinfection with leptospirosis, malaria, yellow fever, typhoid and typhus [7, 44, 51] possibly contributed to the fatalities, as could scurvy [50]. Nonetheless, the most likely candidate jaundice-engendering disease remains a viral hepatitide.

Which one? Hepatitis E seems improbable. Particularly in regard to the Civil War, during which women mingled closely and multifariously with the soldiers in and out of the field [52], no reports of fatal jaundice among pregnant women are apparent. How about hepatitis A? Given that hepatitis A outbreaks in the USA would not have emerged until the last three decades of the 19th century (Fig. 2), and therefore hepatitis A virus (HAV) was not circulating until that period, hepatitis A may not be the candidate, contrary to the received view [18]. However, as juvenile-predominant (hepatitis-A-like) jaundice epidemics had already broken out in Europe [38, 39] prior to the Civil War (Fig. 2), the possibility that HAV was introduced from Europe to the American Continent before or at onset of the war cannot be discounted (Woodward reported that within the first year of war there were already $>10000$ cases of jaundice in the Union Army [50]). If so, the Civil War - that 'last great armed conflict in the world fought without knowledge of the germ theory of disease [53]' could have facilitated the establishment of HAV endemicity in the USA. Given its upheaval and disruption, that war may have set the stage for the hepatitis A epidemics that would soon break out across the country [1-16]. A caveat against ascribing a European introduction of HAV to participants of the Civil War is that, unlike the American War of Revolution and the War of 1812, it was not fought against Europeans or involved European military intervention [54]. European military personnel might not have imported hepatitis A to the USA.

\section{LIMITATIONS}

The enquiry into community-wide outbreaks was not based on formal notification data, whether regional or national. All case counts in the Group I and II outbreaks, even if reported with population counts, allow only crude attack rates to be determined. Sexor age-adjusted rates cannot be calculated as data on the sex distribution of the cases and base populations were seldom reported, if at all. These limitations blunt 
assessments of disease predilections for specific sex and age groups. Furthermore, the dearth of juveniles or pregnant women at the outbreak locations could lead to the non-assignment of Group II outbreaks to hepatitis A or E, respectively. Lastly, the outbreaks in both groups related only to clinically overt cases, with asymptomatic cases unaccounted for.

The chronological assessment showing the Civil War as having occurred before the emergence of epidemic hepatitis A and the Group I outbreaks (Fig. 2) rests on a small number of outbreak reports, and is therefore tenuously based. Examination of other historical documents, if extant and available, may confer more precision to chronological assessments. PCR and sequencing studies when successfully carried out in tissues archived from jaundiced patients [55] from the 19th century may also help to identify the icterogenic agents.

\section{CONCLUSIONS}

Excess clinical attack rates among juveniles feature in community-wide outbreaks of jaundice caused by hepatitis A, as do excess mortality rates among pregnant women during outbreaks of hepatitis E. The unique and disparate demographic predilections of these two viral hepatitides permit inferences of their emergence and endemicity. In the USA, epidemic hepatitis A emerged over the last three decades of the 19th century. During this period, hepatitis-E-like outbreaks were also in occurrence, suggesting either co-emergence with hepatitis A or prior establishment of hepatitis E endemicity. The hepatitis-E-like outbreaks then ceased, contrasting with hepatitis A outbreaks whose number grew. Another class of outbreaks, those that were non-juvenile-predominant but not bearing hepatitis $\mathrm{E}$ features, antedated the 1870s; the disease(s) underlying those outbreaks remain(s) unknown. The Civil War broke out before that period. If hepatitis A had not yet established endemicity, it would not have caused jaundice that was widespread during the war. However, hepatitis A could have been introduced just prior to the war or during its early phases. If so, the war may be viewed to have fostered the spread of hepatitis A through to the 20th century.

\section{ACKNOWLEDGEMENTS}

The author records his gratitude to MA Purdy and TV Murphy for their critical reading of the manuscript.

\section{REFERENCES}

1. Sweet AL. An epidemic of jaundice. Epitome 1888; 25 : 229-230.

2. Garnett AYP. Epidemic jaundice among children. Journal of the American Medical Association 1883; I: 321-325.

3. Davis NS. Cold water enemata in catarrhal jaundice. Journal of the American Medical Association 1886; 7: $13-14$.

4. Foster TA. Report of the Committee on the prevailing diseases of the year. Cumberland County. Transactions of the Maine Medical Association 1870; 3: 232-240.

5. Walker J. Epidemic jaundice in children and youth. Transactions of the Maine Medical Association 18891891; 10: 119-225.

6. Leslie FE. An epidemic of catarrhal jaundice. Boston Medical and Surgical Journal 1909; 161: 622-623.

7. Neill MH. The problem of acute infectious jaundice in the United States. Public Health Reports 1918; 33: 717-726.

8. Blumer G. Infectious jaundice in the United States. Journal of the American Medical Association 1923; 81: 353-358.

9. Williams H. Epidemic jaundice in New York State, 1921-1922. Journal of the American Medical Association 1923; 80: 532-534.

10. Sherman IL, Eichenwald HF. Viral hepatitis: descriptive epidemiology based on morbidity and mortality statistics. Annals of Internal Medicine 1956; 44: 1049-1069.

11. Mosley WH, Speers JF, Chin TOY. Epidemiologic studies of a large urban outbreak of infectious hepatitis. American Journal of Public Health 1963; 53: 1603 1617.

12. Mosley JW, Kendrick MA. Hepatitis as a world problem. Bulletin of the New York Academy of Medicine 1969; 45: 143-166.

13. Crusberg TC, Burke WM, Reynolds JT, Morse LE, Reilly J, Hoffman AH. The reappearance of a classical epidemic of infectious hepatitis in Worcester, Massachusetts. American Journal of Epidemiology 1978; 107: 545-551.

14. Shaw FE, Sudman JH, Smith SM, Williams DL, Kapell LA, Hadler SC et al. A community-wide epidemic of hepatitis A in Ohio. American Journal of Epidemiology 1986; 123: 1057-1065.

15. Capps RB, Bennett AM, Mills EH, Ettinger RH, Drake ME, Stokes Jr J. Infectious hepatitis in infants and small children; the clinical and laboratory picture, with special reference to the nonicteric form. American Journal of Diseases of Childhood 1955; 89: 701-716.

16. Wasley A, Fiore A, Bell BP. Hepatitis A in the era of vaccination. Epidemiological Reviews 2006; 28: 101-111.

17. Ackerknecht EH. The vagaries of the notion of epidemic hepatitis or infectious jaundice. In: Stevenson LG, Multhauf RP, eds. Medicine, Science and Culture. Historical Essays in Honor of Owsei Temkin. Baltimore: Johns Hopkins Press, 1968, pp. 3-16.

18. Zuckerman AJ. The history of viral hepatitis from antiquity to the present. In: Deinhardt F, Deinhardt J, 
eds. Viral Hepatitis: Laboratory and Clinical Science. New York: Marcel Dekker, 1983, pp. 3-32.

19. Zimmerman HY. Hepatotoxicity. The Adverse Effects of Drug and Other Chemicals on the Liver, 2nd edn. Philadelphia: Lippincott, Williams and Wilkins, 1999, pp. 751.

20. Gordon-Taylor G. On gallstones and their sufferers. British Journal of Surgery 1937; 25: 241-251.

21. Public Library of the City of Boston. The Prince Library: A Catalogue of the Collection of Books and Manuscripts which Formerly Belonged to the Reverend Thomas Prince. Boston: Alfred Mudge \& Son, 1879, p. 160.

22. Reynolds HH. Reminiscences of Dr. Jacob Roebeck. In: Hemenway AB, ed. The Vermont Historical Gazette. Vol. II: Franklin, Grand Isle, Lamoille and Orange Counties. Burlington, VT: Hemenway AB, 1871, pp. 548-550.

23. Wood HC. A case of leucinosis. American Journal of Medical Sciences 1867; 106: 418-432.

24. Smith CE. A synopsis of ten cases of jaundice occurring in pregnant women. Northwestern Medical and Surgical Journal 1874: 436-440.

25. Sears JW. The Birmingham epidemic of jaundice. Transactions of the Medical Association of the State of Alabama 1882: 472-480.

26. Young WB. Simple and malignant jaundice of pregnancy: report of three cases. Medical News 1898; 78: 618-621.

27. Runyon FJ. Epidemic catarrhal icterus as a complication of pregnancy. Memphis Medical Monthly 1902; 23: 281-285.

28. Dixon DP. Epidemic of jaundice in Talladega. Transactions of the Medical Association of the State of Alabama 1908: 439-446.

29. Clark CJ. Jaundice as an epidemic. Boston Medical Surgical Journal 1850; 42: 521-524.

30. Corson H. Epidemic jaundice in Montgomery County, Pa. Medical Examiner 1855; 127: 387-394.

31. Pierson W. Epidemic jaundice. Transactions of the Medical Society of the State of New Jersey 1859; 8: 251-252.

32. Shaffner JF. Epidemic jaundice. Baltimore Journal of Medicine 1861; 1: 120-124.

33. Teo CG. Fatal outbreaks of jaundice in pregnancy and the epidemic history of hepatitis E. Epidemiology and Infection 2012; 140: 767-787.

34. Jacobsen KH, Wiersma ST. Hepatitis A virus seroprevalence by age and world region, 1990 and 2005. Vaccine 2010; 28: 6653-6657.

35. MacArthur W. Historical notes on some epidemic diseases associated with jaundice. British Medical Bulletin 1957; 13: 146-149.

36. Hirsch A. Handbook of Geographical and Historical Pathology. Vol. III: Diseases of Organs and Parts (translated by Creighton C). London: New Sydenham Society, 1886 , pp. 780.

37. Hinssen M. Ein Beitrag zur Geschichte der Hepatitis-Infectiosa-Epidemien in Europa vom Ende des 17. Bis zur Mitte des 19. Jahrhunderts [in German].
Dissertation, Dusseldorf: University of Dusseldorf, 1966, pp. 69.

38. Brüning GFH. Tractatus de Ictero Spasmodica Infantum [in Latin]. Versailles and Leipzig, 1773, p. 403.

39. Barker TH. Epidemic jaundice in children. Association Medical Journal 1854; 53: 80-83.

40. Rehn H. Eine Ikterus-Epidemie. Jahrbuch für Kinderheilkunde und physische Erziehung [in German] 1870; 3: 197-203.

41. Anderson LS. Infective jaundice in Iceland. Lancet 1947; ii: $776-781$.

42. MacCallum FO, McFarlan AM, Miles JAR, Pollock MB, Wilson C. Infective Hepatitis: Studies in East Anglia During the Period 1943-47. Special Report Series Medical Research Council No. 273. London: Her Majesty's Stationery Office, 1951, pp. 144.

43. Bachmann L. Hepatitis epidemica in Europa. In: Rodenwaldt E, ed. World Atlas of Epidemic Diseases. Part I. Hamburg: Falk-Verlag, 1952, pp. 67-76.

44. Surgeon-General's Office, U.S. Army. The Medical and Surgical History of the War of The Rebellion. Part I. Volume I (Medical History). Washington, DC: Government Printing Office, 1870, pp. 726.

45. Faulkner L. On epidemic jaundice. Maryland and Virginia Medical Journal 1860; 15: 355-358.

46. Butler SL. Guide to Virginia Militia Units in the War of 1812. Athens, GA: Iberian Publishing, 1988, p. 45.

47. Sharp WD. The confederate states medical and surgical journal: 1864-1865. Bulletin of the New York Academy of Medicine 1976; 52: 373-418.

48. Roberts B. Desolation itself: the impact of the Civil War. In: Whayne JM, Gatewood WB, eds. The Arkansas Delta: Land of Paradox. Fayetteville, AR: University of Arkansas Press, 1993, pp. 70-93.

49. Baird ND. There is no Sunday in the army: civil war letters of Lunsford P Yandell, 1861-62. Filson Club Historical Quarterly 1979; 53: 319-327.

50. Woodward JJ. Outlines of the Chief Camp Diseases as Observed during the Present War. Philadelphia: Lippincott \& Co, 1863, pp. 364.

51. Steiner PE. Disease in The Civil War: Natural Biological Warfare in 1861-1865. Springfield, IL: Charles C. Thomas, 1968, pp. 243.

52. Harper JE. Women during the Civil War. An Encyclopedia. New York: Routledge, 2004, pp. 533.

53. Sartin JS. Infectious diseases during the Civil War: the triumph of the 'Third Army'. Clinical Infectious Diseases 1993; 16: 580-584.

54. Doyle DH. The Cause of All Nations. An International History of the American Civil War. New York: Basic, 2015, pp. 382.

55. Ganova-Raeva L, Punkova L, Campo DS, Dimitrova Z, Skums P, Vu NH et al. Cryptic hepatitis B and E in patients with acute hepatitis of unknown etiology. Journal of Infectious Diseases 2015; 15: 1962-1969. 